\title{
Masa Depan Arbitrase sebagai Mekanisme Penyelesaian Perselisihan Hubungan Industrial di Indonesia
}

\author{
Mila Karmila Adi \\ Fakultas Hukum Universitas Islam Indonesia \\ Jl. Tamansiswa No. 158 Yogyakarta \\ milakarmila@fh.uii.ac.id.
}

\begin{abstract}
The unresolved clash between the employees and employers may result a fire or resignation. Generally, it makes the unexpected condition worse for both. In the case of a fire, the employees will face a bad future without job. The research is focused on the arbitrary possibility as a solution for their need to solve the clash between employees and employers. It is done through normative and comparative approach, and secondary data analysis. The result shows that an arbitrary has three characteristics; they are simple, fast and cheap, which is suitable to maintain a good working relationship in Indonesia. Yet, it has some weaknesses that mainly relate to expense and fee for the arbitrary team paid by those parties. Thus, this arbitrary mechanism is unlikely to be used in majority.
\end{abstract}

Key words : Arbitrage, employment relationship, and dispute resolution.

\begin{abstract}
Abstrak
Perselisihan antara pekerja dan pengusaha yang tidak dapat diselesaikan dapat berakhir dengan pemutusan hubungan kerja atau pengunduran diri. Secara umum, hal tersebut akan memperburuk kondisi yang tidak diinginkan oleh para pihak, baik pekerja maupun pengusaha. Khususnya dalam kasus pemutusan hubungan kerja yang dilakukan oleh pengusaha, pekerja akan menghadapi masa depan yang lebih buruk ketika pekerja tidak mempunyai pekerjaan lagi. Penelitian ini difokuskan pada kemungkinan arbitrase sebagai prosedur damai yang cocok bagi kebutuhan para pihak dalam penyelesaian perselisihan antara pekerja dan pengusaha. Melalui metode pendekatan yuridis normatif dan komparatif, dan analisis data sekunder. Penelitian ini menyimpulkan bahwa arbitrase mempunyai tiga karakteristik, yaitu sederhana, cepat, dan murah, yang cocok untuk menjaga kelangsungan hubungan kerja di Indonesia, akan tetapi arbitrase mempunyai beberapa kelemahan yang utamanya terkait dengan biaya dan honor bagi arbiter/tim arbiter yang harus dibayar oleh para pihak. Dengan demikian, akan kecil kemungkinan bagi para pihak untuk menggunakan arbitrase sebagai mekanisme penyelesaian perselisihannya di masa datang.
\end{abstract}

Kata kunci : Arbitrase, hubungan kerja, penyelesaian perselisihan. 


\section{Pendahuluan}

Perselisihan antara pekerja dan pengusaha dalam suatu hubungan kerja adalah suatu hal yang wajar terjadi. Namun demikian, jika suatu perselisihan tidak dapat diselesaikan akan menimbulkan dampak yang buruk tidak hanya bagi para pihak, juga secara tidak langsung bagi perekonomian Indonesia. Terutama pada masa krisis, antara lain timbulnya demonstrasi, mogok kerja, dan pemutusan hubungan kerja, yang kesemuanya dapat terjadi karena perselisihan yang tidak dapat diselesaikan antara kedua belah pihak.

Kelangsungan suatu hubungan kerja diperlukan oleh para pihak, pekerja dan pengusaha. Suatu mekanisme yang damai diperlukan untuk menyelesaikan perselisihan di antara mereka, karena para pihak memiliki suatu kepentingan yang tinggi dalam hubungan mereka. Di satu pihak, pengusaha sebagai pebisnis menginginkan untuk memperoleh keuntungan sebanyak mungkin dari usahanya. Di lain pihak, pekerja menginginkan upah setinggi-tingginya dari pekerjaan yang dilakukan untuk membiayai kebutuhan hidupnya. Kepentingan-kepentingan yang berbeda tersebut seringkali membuat para pihak dalam suatu posisi yang berbeda dan menjadikan mereka pada kondisi yang saling bertentangan.

Dengan demikian, pekerja dan pengusaha membutuhkan suatu mekanisme penyelesaian perselisihan yang dapat menyelesaiakan perselisihan mereka tanpa menjadikan hubungan kerja mereka berakhir.

Perselisihan antara pekerja dan pengusaha yang tidak dapat diselesaikan dapat berakhir dengan pemutusan hubungan kerja atau pengunduran diri. Secara umum, hal tersebut akan memperburuk kondisi yang tidak diinginkan oleh para pihak, baik pekerja maupun pengusaha. Khususnya dalam kasus pemutusan hubungan kerja yang dilakukan oleh pengusaha, pekerja akan menghadapi masa depan yang lebih buruk ketika pekerja tidak mempunyai pekerjaan lagi. Pekerja tidak memiliki modal selain dari tenaganya sendiri. Jumlah angkatan kerja di Indonesia juga sedemikian besar dan pengangguran juga banyak. Hal itulah yang menjadikan pemutusan hubungan kerja menjadi mimpi buruk bagi pekerja. Dengan demikian, pekerja dan pengusaha membutuhkan suatu mekanisme penyelesaian perselisihan yang dapat menyelesaiakan perselisihan mereka tanpa menjadikan hubungan kerja mereka berakhir. 
Komar Kantaatmadja secara garis besar menggolongkan penyelesaian sengketa dalam tiga golongan, yaitu: ${ }^{1} 1$. Penyelesaian sengketa dengan menggunakan negosiasi, baik berupa negosiasi yang bersifat langsung maupun dengan penyertaan pihak ketiga. 2. Penyelesaian sengketa dengan cara litigasi, baik yang bersifat nasional maupun internasional. 3. Penyelesaian sengketa dengan menggunakan arbitrase, baik yang bersifat ad hoc maupun yang terlembaga.

Secara umum Undang-Undang Nomor 13 Tahun 2003 tentang Ketenagakerjaan, selanjutnya disebut UU 13 Tahun 2003, menganut penyelesaian sengketa atau perselisihan didasarkan atas prinsip musyawarah untuk mufakat, yang berarti bahwa setiap perselisihan antara pekerja dan pengusaha harus diselesaikan melalui suatu mekanisme yang damai. ${ }^{2}$ Prinsip ini juga mendasari peraturan perundangan lainnya yang mengatur tentang penyelesaian perselisihan ketenagakerjaan, yaitu Undangundang Nomor 22 Tahun 1957 tentang Penyelesaian Perselisihan Perburuhan yang sudah tidak berlaku, dan Undang-undang Nomor 2 Tahun 2004 tentang Penyelesaian Perselisihan Hubungan Industrial yang menggantikan UU Nomor 22 Tahun 1957.

Arbitrase adalah salah satu mekanisme yang disediakan baik oleh Undangundang Nomor 22 Tahun 1957, selanjutnya disebut UU PPP, maupun oleh Undangundang Nomor 2 Tahun 2004, selanjutnya disebut UU PPHI. Arbitrase menyediakan suatu prosedur yang damai atau mekanisme non-litigasi (di luar pengadilan). Hal ini berarti bahwa mekanisme arbitrase dilakukan melalui arbiter/tim arbiter di luar lembaga pengadilan dan menggunakan penyelesaian win-win, yaitu kedua belah pihak sama-sama menang atau diuntungkan. Melalui prosedur arbitrase, para pihak dapat mencapai suatu penyelesaian yang sederhana, cepat, dan murah, dibandingkan dengan prosedur pengadilan yang dilakukan dalam pengadilan perburuhan. Jadi, arbitrase adalah mekanisme damai yang dapat membawa para pihak ke dalam situasi yang damai dan menjaga hubungan mereka tetap berlangsung.

Walaupun arbitrase memiliki prosedur yang damai yang cocok untuk menyelesaikan suatu perselisihan ketenagakerjaan, namun kenyataannya sejak arbitrase diatur dalam UU PPP pada 1957, dan sekarang telah digantikan dengan UU PPHI pada 2004, arbitrase belum pernah digunakan oleh para pihak untuk menyelesaikan perselisihan mereka.

\footnotetext{
${ }^{1}$ Huala Adolf, Arbitrase Komersial Internasional, Cetakan Kedua, Rajawali, Jakarta, 1993, hlm. 4.

${ }^{2}$ Pasal 136 ayat (1) UU 13/2003.
} 


\section{Rumusan Masalah}

Berdasarkan latar belakang penelitian di atas, permasalahan penelitian ini adalah: Pertama, mengapa arbitrase tidak pernah digunakan; Kedua, bagaimana masa depan arbitrase bagi kelangsungan hubungan kerja di Indonesia.

\section{Tujuan Penelitian}

Penelitian bertujuan untuk mengetahui: Pertama, untuk mengetahui faktor-faktor mengapa arbitrase tidak pernah digunakan dan; Kedua, bagaimana masa depan arbitrase bagi kelangsungan hubungan kerja di Indonesia.

\section{Metode Penelitian}

Metode pendekatan yang digunakan dalam penelitian ini adalah yuridis normatif dan komparatif terhadap keberadaan arbitrase sebagai salah satu mekanisme penyelesaian perselisihan hubungan industrial dan masa depan arbitrase. Metode yuridis normatif adalah pendekatan dari sudut pandang ketentuan hukum atau peraturan perundang-undangan yang berlaku, yang menyangkut peraturan perundang-undangan ketenagakerjaan terutama penyelesaian perselisihan hubungan industrial, khususnya arbitrase. Metode ini juga digunakan untuk melakukan penelusuran terhadap sejarah perkembangan arbitrase dalam peraturan perundangundangan ketenagakerjaan di Indonesia.

Metode komparatif adalah metode pendekatan dengan membandingkan pengaturan arbitrase dalam peraturan perundang-undangan, yaitu UU Nomor 22 Tahun 1957 tentang PPP dan UU Nomor 2 Tahun 2004 tentang PHI, dari segi prinsip, prosedur, dan pembiayaan arbitrase, baik dari hasil penelitian sebelumnya maupun studi kepustakaan dan studi dokumen.

Analisis data menggunakan analisis deskriptif kualitatif dengan kegiatan mengolah data yang meliputi editing, coding dan penyajian dalam bentuk narasi. Data diuraikan, dibahas dan ditafsirkan dengan perspektif dan sudut pandang tertentu untuk merumuskan kesimpulan dari pertanyaan penelitian yang diajukan. 


\section{Hasil Penelitian dan Pembahasan}

\section{Sejarah Pengaturan Arbitrase sebagai Mekanisme Penyelesaian Perselisihan Hubungan Industrial dalam Peraturan Ketenagakerjaan.}

Arbitrase secara umum dikenal sebagai mekanisme yang dibentuk untuk penyelesaian perselisihan dalam suatu hubungan bisnis. Hal ini sebagaimana diatur dalam Undang-Undang Nomor 30 Tahun 1999 tentang Arbitrase dan Alternatif Penyelesaian Sengketa, selanjutnya disebut UU AAPS. UU AAPS mengatur beberapa mekanisme yang disediakan untuk perselisihan antar pengusaha di luar lembaga pengadilan (non-litigasi). Arbitrase bukan suatu mekanisme baru di Indonesia, karena telah diatur, misalnya, di dalam Het Herzienen Indonesisisch Reglement, Staatsblad 1941; 44, selanjutnya disebut HIR. HIR merupakan buatan pemerintah Hindia Belanda untuk wilayah Jawa dan menjadi sumber hukum bagi AAPS. ${ }^{3}$

Arbitrase dan alternatif penyelesaian sengketa lainnya adalah mekanismemekanisme secara damai, karena diputus berdasarkan suatu penyelesaian win-win, dan memiliki prosedur yang sederhana, cepat, dan murah. Karakteristik tersebut merupakan kelebihan dari arbitrase dibandingkan dengan prosedur di muka pengadilan (litigasi), karena di antara para pihak membutuhkan suatu mekanisme yang dapat mempertahankan kelangsungan hubungan bisnis mereka. Hal ini ditunjukkan dalam sejarah keberadaan arbitrase sejak kesan tentang pengadilan sebagai "usaha pertama dan terakhir" menurun. ${ }^{4}$

Arbitrase adalah suatu prosedur yang oleh para pihak yang berselisih secara sukarela setuju untuk terikat pada putusan pihak ketiga yang netral di luar proses pengadilan yang normal. ${ }^{5}$ Logika dan kesederhanaan dari arbitrase mendapat pujian bahwa proses tersebut ditujukan untuk manusia sejak abad permulaan. ${ }^{6}$ Untuk alasan yang sama pula arbitrase secara luas diterima sebagai pelengkap bagi hukum formil dari orang-orang Romawi dan lebih disukai sebagai alat penyelesaian perselisihan komersial pada Abad Pertengahan. ${ }^{7}$

\footnotetext{
${ }^{3}$ Lalu Husni, Penyelesaian Perselisihan Hubungan Industrial melalui Pengadilan \& di luar Pengadilan, PT. RajaGrafindo Persada, Jakarta, 2004, hlm. 70.

${ }^{4}$ M. Yahya Harahap dikutip oleh Rachmadi Usman, Piliban Penyelesaian Sengketa di luar Pengadilan, PT. Citra Aditya Bakti, Bandung, 2003, hlm. 10.

${ }^{5}$ Diterjemahkan secara bebas dari Dennis R Nolan, Labor Arbitrase Law and Practice, West Publishing Company, Minnesota, 1979, hlm. 1.

${ }^{6}$ Ibid., hlm. 2.

${ }^{7}$ Ibid., hlm. 3.
} 
Arbitrase yang dimaksud dalam penelitian ini adalah arbitrase di bidang ketenagakerjaan. Arbitrase ketenagakerjaan, pada awalnya, diatur dalam UU PPP yang telah mengatur arbitrase sebagai salah satu mekanisme bagi suatu perselisihan hubungan kerja antara pekerja dan pengusaha. Kemudian, pada saat ini arbitrase diatur dalam UU PPHI.

UU PPP pada dasarnya menyediakan 2 (dua) jenis mekanisme penyelesaian perselisihan, yaitu mekanisme sukarela dan mekanisme wajib. Masing-masing mekanisme dapat dipilih jika para pihak tidak dapat menyelesaikan perselisihan mereka melalui perundingan internal (bipartit) sebagai proses pertama dan utama yang harus dilalui oleh para pihak sebagaimana dalam prinsip ‘musyawarah untuk mufakat'.

Mekanisme sukarela, yang disebut sebagai arbitrase dijalankan oleh seorang juru pemisah atau dewan pemisah, yang biasa disebut sebagai arbiter, yang berwenang menyelesaikan suatu perselisihan dengan suatu putusan yang final and binding. Hal ini berarti bahwa putusan arbiter tidak dapat diajukan banding karena merupakan putusan yang terakhir, dan berkekuatan hukum tetap sehingga mengikat kedua belah pihak untuk dilaksanakan. Putusan arbiter dapat dilaksanakan jika putusan tersebut dimintakan pengesahannya ke Panitia Penyelesaian Perselisihan Perburuhan (P4) Pusat. Pengesahan putusan arbiter oleh P4 Pusat akan menimbulkan 2 (dua) konsekuensi, yaitu (1) putusan arbiter yang telah disahkan tersebut dapat dimintakan fiat eksekusi ke pengadilan negeri setempat; dan (2) pihak yang tidak melaksanakan putusan yang telah disahkan tersebut dapat dikenai denda dan/atau kurungan maksimal 3 (tiga) bulan.

Mekanisme wajib, di pihak lain, merupakan mekanisme yang wajib dilakukan oleh para pihak apabila tidak dapat menyelesaikan perselisihan mereka secara internal (bipartit) dan para pihak tidak memilih mekanisme sukarela untuk menyelesaikan perselisihannya. Berbeda dengan mekanisme sukarela, mekanisme wajib melibatkan banyak pejabat/lembaga pemerintah, yaitu Pegawai Perantara, Panitia Penyelesaian Perselisihan Perburuhan (P4) Daerah, Panitia Penyelesaian Perselisihan Perburuhan (P4) Pusat. Mekanisme wajib dapat dilakukan secara bertahap dari tahap terendah, yaitu pegawai perantara, sampai tahap tertinggi, yaitu P4 Pusat. Pada mekanisme ini, P4 Pusat secara formil adalah lembaga penyelesai tertinggi, sehingga tidak dapat dilakukan upaya hukum atas putusan P4 Pusat. UU PPP memberikan kewenangan kepada Menteri Tenaga Kerja untuk melakukan penundaan atau bahkan pembatalan 
(veto) terhadap putusan P4 Pusat, apabila Menteri mempertimbangkan adanya kepentingan umum yang terkait di dalam perselisihan tersebut.

Mekanisme wajib bukan merupakan peradilan khusus di bidang ketenagakerjaan, akan tetapi merupakan suatu "peradilan semu", yaitu sebagai salah satu upaya administratif sebagaimana diatur dalam Pasal 48 Undang-undang Nomor 5 Tahun 1986 tentang Peradilan Tata Usaha Negara. ${ }^{8}$ Upaya administratife ini merupakan bagian dari pengertian peradilan administrasi dalam arti luas. ${ }^{9}$

Arbitrase, saat ini, diatur oleh UU PPHI yang menggantikan UU PPP. Ada beberapa mekanisme yang disediakan UU PPHI untuk penyelesaian perselisihan ketenagakerjaan, yaitu bipartit, mediasi, konsiliasi, arbitrase, dan pengadilan hubungan industrial.

Bipartit adalah suatu mekanisme yang pertama-tama harus dilakukan oleh para pihak dalam menyelesaikan perselisihan mereka di tingkat internal atau di lingkungan perusahaan, sehinggga tidak ada atau belum melibatkan campur tangan pihak ketiga. Mekanisme ini adalah mekanisme yang pertama dan utama yang harus dilakukan oleh para pihak sebagaimana prinsip musyawarah untuk mufakat. Jika para pihak, pekerja dan pengusaha, tidak dapat menyelesaikan perselisihan melalui mekanisme bipartit, para pihak kemudian dapat memilih di antara 3 (tiga) mekanisme penyelesaian perselisihan, yaitu mediasi, atau konsiliasi, atau arbitrase.

Mediasi and Konsiliasi adalah dua mekanisme yang memiliki prosedur yang sama akan tetapi dilakukan oleh dua institusi yang berbeda. Mediasi dipimpin oleh seorang perantara, yaitu seorang pegawai pemerintah (pegawai perantara) pada Dinas Tenaga Kerja dan Transmigrasi tingkat Kota/Kabupaten, sedangkan konsiliasi dipimpin oleh seorang konsiliator yang bukan seorang pegawai pemerintah. Baik pegawai perantara maupun konsiliator, dalam menjalankan tugasnya untuk menyelesaian perselisihan para pihak tidak memiliki kewenangan untuk memberikan suatu putusan, akan tetapi hanya berwenang untuk memberikan suatu anjuran tertulis bagi para pihak yang akan mencapai kesepakatan mereka sendiri. ${ }^{10}$ Apabila para pihak tidak dapat menerima anjuran tertulis dari pegawai perantara atau konsiliator sehingga para pihak pada dasarnya tidak dapat mencapai kesepakatan melalui mekanisme mediasi

${ }^{8}$ Sjahran Basah, Eksistensi dan Tolok Ukur Badan Peradilan Administrasi di Indonesia, Cetakan Ketiga, Alumni, Bandung, 1997, hlm. 63.

${ }^{9}$ Rochmat Soemitro, Masalah Peradilan Administrasi dalam Hukum Pajak di Indonesia, Eresco, Bandung, 1976, hlm. 51 .

${ }^{10}$ Lihat juga Dennis R Nolan, Op.Cit., hlm. 4. 
atau konsiliasi, para pihak dapat mengajukan penyelesaian perselisihannya melalui pengadilan hubungan industrial.

Arbitrase, pada dasarnya merupakan mekanisme penyelesaian yang sederhana, cepat dan murah, karena arbitrase dipimpin oleh arbiter yang memiliki kewenangan untuk memberikan putusan untuk menyelesaikan perselisihan. Dengan memilih mekanisme arbitrase, berarti para pihak bersepakat untuk menerima apapun putusan dari arbiter yang bertindak selaku 'hakim' dalam penyelesaian perselisihan. Putusan arbiter adalah putusan yang bersifat final (terakhir) dan binding (mengikat) yang berarti bahwa putusan itu sah dan tidak dapat dilakukan upaya hukum apapun ke lembaga lain, bahkan ke pengadilan hubungan industrial sekalipun. Putusan arbitrase juga berarti dapat diajukan permohonan fiat eksekusi kepada pengadilan hubungan industrial setempat, kecuali ada peninjauan kembali dari Mahkamah Agung atas putusan tersebut, putusan tersebut dapat dibatalkan oleh Mahkamah Agung.

Mekanisme terakhir adalah melalui pengadilan hubungan industrial, selanjutnya disebut PHI, yang berada di bawah pengadilan negeri setempat sebagai suatu pengadilan khusus di bidang ketenagakerjaan, sehingga hukum acara yang berlaku di dalamnya adalah hukum acara perdata. Sebagai pengadilan khusus, mekanisme pada PHI juga memiliki kekhususan yang menyangkut putusan PHI, yaitu (1) untuk perselisihan hak maupun perselisihan PHK (pemutusan hubungan kerja), putusan PHI dapat diajukan kasasi ke Mahkamah Agung. (2) untuk perselisihan kepentingan atau perselisihan antar Serikat Pekerja dalam satu perusahaan, putusan PHI adalah putusan terakhir yang tidak dapat diajukan kasasi ke Mahkamah Agung. PHI dapat dipilih sebagai mekanisme penyelesaian perselisihan bagi para pihak apabila tidak dapat menyelesaikan perselisihan melalui mediasi atau konsiliasi.

\section{Perbandingan Arbitrase sebagai Mekanisme Penyelesaian Perselisihan berdasarkan UU PPP dan UU PPHI.}

Arbitrase dalam UU PPHI dapat dibandingkan dengan arbitrase dalam UU PPP, karena pengaturan arbitrase ketenagakerjaan pada dasarnya ada di dalam kedua UU tersebut. Akan tetapi dalam praktiknya arbitrase tidak pernah dipilih oleh para pihak untuk menyelesaiakan perselisihan di bidang ketenagakerjaan sejak diatur di dalam UU PPP. ${ }^{11}$

${ }^{11}$ Lihat hasil penelitian Mila Karmila Adi, Penyelesaian Sengketa Ketenagakerjaan secara Arbitrase di Indonesia dalam Era Globalisasi, Tesis, Program Pascasarjana, Universitas Padjadjaran, Bandung, 2002, hlm. 245. 
UU PPP menempatkan arbitrase sebagai mekanisme sukarela ${ }^{12}$ yang berarti arbitrase dapat dipilih oleh para pihak ketika mereka tidak dapat menyelesaikan perselisihannya melalui mekanisme bipartite dan mereka secara 'sukarela' sepakat untuk memilih arbitrase. Atau arbitrase dapat dipilih para pihak yang menyetujui usulan atau saran dari P4 Daerah, dengan syarat ada suatu perjanjian tertulis untuk menyelesaikan perselisihan mereka melalui arbitrase. ${ }^{13}$

Pihak yang memimpin penyelesaian perselisihan dalam arbitrase, yaitu arbiter, disebut sebagai juru atau dewan pemisah yang memiliki kewenangan untuk menyelesaikan perselisihan para pihak dengan suatu putusan yang bersifat terakhir dan mengikat. Konsekuensi dari putusan juru atau dewan pemisah tersebut adalah, bahwa, para pihak wajib menerima apapun putusan dari juru atau dewan pemisah. Hal inilah yang menjadikan arbitrase sebagai mekanisme penyelesaian yang sederhana, karena hanya memerlukan satu tahapan pelaksanaan pada tingkat juru atau dewan pemisah.

Arbitrase ketenagakerjaan pada dasarnya adalah suatu arbitrase bagi perselisihan antara pengusaha dan serikat pekerja yang mewakili pekerja yang melibatkan beberapa aspek dari hubungan kerja. Perselisihan-perselisihan tersebut ada dua jenis: (1) perselisihan kepentingan; yang menunjukkan adanya ketidaksepahaman atas ketentuan-ketentuan yang akan dimasukkan dalam suatu perjanjian, yang disebut perjanjian perburuhan ${ }^{14}$ antara pekerja dan serikat pekerja sebagai wakil pekerja; dan (2) perselisihan hak atau 'keluhan'; yang menunjukkan ketidaksepahaman atas pemahaman atau penerapan dari ketentuan-ketentuan yang terkandung dalam suatu perjanjian kerja bersama. ${ }^{15}$

UU PPP juga mengatur dua jenis perselisihan, yaitu perselisihan kepentingan dan perselisihan hak. Pengertian perselisihan kepentingan (belangen-geschillen) dan perselisihan hak (rechtsgeschillen) yang dimaksud, sebagaimana dikemukakan oleh Iman Soepomo, ${ }^{16}$ ada perbedaan dengan pendapat Dennis R. Nolan tersebut di atas:

\footnotetext{
${ }^{12}$ Lihat bab sebelumnya tentang Sejarah Arbitrase sebagai Mekanisme Penyelesaian Perselisihan Hubungan Industrial dalam Peraturan Ketenagakerjaan, di atas.

${ }^{13}$ Pasal 19 ayat (1) dan (2) UU PPP.

${ }^{14}$ Istilah 'perjanjian perburuhan' (Undang-undang Nomor 21 Tahun1969 tentang Perjanjian Perburuhan antara Serikat Buruh dan Majikan) diubah menjadi 'kesepakatan kerja bersama', kemudian diubah lagi menjadi'perjanjian kerja bersama'.

${ }^{15}$ Diterjemahkan secara bebas dari Dennis R. Nolan, Op.Cit., hlm. 2.

${ }^{16}$ Iman Soepomo, Hukum Perburuban Bidang Hubungan Kerja, cetakan kedelapan, Djambatan, Jakarta, 1994, hlm. 177.
} 
“Perselisihan hak adalah perselisihan yang timbul karena salah satu pihak dalam perjanjian kerja atau perjanjian perburuhan (perjanjian kerja bersama - pen.) tidak memenuhi isi perjanjian tersebut ataupun menyalahi ketentuan hukum, sedangkan perselisihan adalah mengenai usaha mengadakan perubahan dalam syarat perburuhan, biasanya perbaikan syarat perburuhan yang oleh organisasi buruh dituntutkan kepada pihak majikan."

Kedua jenis perselisihan tersebut dapat diselesaikan melalui juru atau dewan pemisah atau disebut arbitrase. Dalam perkembangannya, perselisihan yang dapat diselesaikan melalui mekanisme arbitrase menurut UU PPP, bertambah dengan diberlakukannya Undang-undang Nomor 12 Tahun 1964 tentang Pemutusan Hubungan Kerja di Perusahaan Swasta, yaitu perselisihan Pemutusan Hubungan Kerja (PHK).

Perbedaan antara arbitrase umum dalam UU AAPS dan arbitrase dalam UU PPP adalah adanya ketentuan bahwa putusan juru atau dewan pemisah dalam arbitrase ketenagakerjaan harus disahkan oleh P4 Pusat agar dapat dimintakan fiat eksekusi ke Pengadilan Negeri setempat atau dijatuhkannya hukuman denda dan atau kurungan maksimal 3 (tiga) bulan kepada pihak yang tidak mau melaksanakan putusan tersebut.

Para pihak menunjuk juru atau dewan pemisah dan menentukan bagaimana mekanisme yang dijalankan, akan tetapi mereka juga harus membayar sendiri biaya penyelesaian perselisihan dan proses persidangan. Tidak ada standar atau aturan yang jelas berapa banyak biaya untuk mekanisme arbitrase, karena itu tergantung pada kesepakatan para pihak atau kasus yang ditangani. Arbitrase juga tidak memiliki aturan yang mutlak, karena arbitrase adalah suatu mekanisme di luar pengadilan, sehingga akan muncul berbagai macam proses arbitrase yang didasarkan atas kesepakatan para pihak yang berselisih.

Tidak ada peraturan tentang siapa yang bisa ditunjuk sebagai juru atau dewan pemisah. Para pihak dapat memilih siapapun yang mereka percaya untuk menjadi juru atau dewan pemisah dan mereka akan memilih siapapun yang mereka anggap dapat berlaku sebagai 'hakim' yang adil. Tidak seorangpun, bahkan pemerintah, dapat ikut campur terhadap pilihan para pihak.

Tidak ada batasan waktu berapa lama mekanisme arbitrase tersebut seharusnya diselesaikan, sehingga mekanisme arbitrase dapat dilakukan lebih lama atau bahkan lebih cepat dari mekanisme wajib. Jadi tidak ada kepastian kapan proses arbitrase itu dapat diselesaikan. 
Proses arbitrase melalui juru atau dewan pemisah dalam UU PPP, secara singkat dapat digambarkan dalam skema di bawah ini:

\section{Skema I.}

Proses Arbitrase

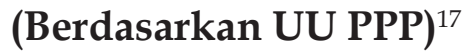

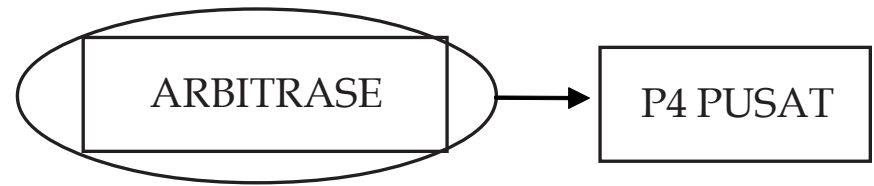

PENGADILAN NEGERI

Keterangan Skema I:

1) Apabila para pihak tidak dapat menyelesaikan perselisihan secara bipartit dan para pihak bersepakat secara sukarela, penyelesaian perselisihan dilanjutkan pada mekanisme arbitrase (juru atau dewan pemisah);

2) Putusan juru/dewan pemisah dapat diajukan pengesahannya kepada P4Pusat yang berkonsekuensi putusan tersebut berkekuatan eksekutorial, yaitu apabila salah satu pihak tidak bersedia melaksantakannnya akan ada dua kemungkinan: a. dapat dimintakan fiat eksekusi ke Pengadilan Negeri setempat; atau b. dijatuhi hukuman kurungan maksimal 3 bulan penjara dan/atau denda.

3) P4Pusat berwenang untuk mengesahkan putusan arbitrase, kecuali: a. Putusan tersebut melampaui kewenangan juru/dewan pemisah; b. Putusan tersebut mengandung itkad buruk; c. Putusan tersebut bertentangan dengan UU kesusilaan dan ketertiban umum.

Demikian juga arbitrase di dalam UU PPHI, saat ini, pada dasarnya memiliki satu tahapan prosedur. Ketika para pihak tidak dapat menyelesaikan perselisihan mereka melalui mekanisme bipartite mereka dapat memilih arbitrase melalui suatu Perjanjian Arbitrase. Hal ini juga berarti bahwa para pihak akan menerima setiap putusan arbiter, karena putusan arbiter adalah terakhir dan mengikat. Putusan arbiter tidak dapat diajukan banding ataupun kasasi, akan tetapi dapat dibatalkan oleh Mahkamah Agung dalam keadaan atau kondisi tertentu. Apabila salah satu pihak tidak mau menerima atau tidak setuju dengan putusan arbiter, pihak lain dapat meminta suatu perintah pelaksanaan putusan (fiat eksekusi) kepada pengadilan (Pengadilan Hubungan Industrial/PHI) agar putusan itu dapat dilaksanakan secara paksa.

\footnotetext{
${ }^{17}$ Analisis ini didasarkan atas Pasal 19-22 UU PPP. Lihat juga Mila Karmila Adi, Op.Cit., hlm. 141.
} 
Para pihak memilih arbiter atau para arbiternya, merundingkan prosedur atau mekanisme penyelesaiannya, dan juga membayar biaya proses arbitrasenya. Hal ini akan membuat mekanisme arbitrase menjadi sederhana dan tidak akan ada standar biaya dalam penggunaan arbitrase yang kemungkinan dapat menjadi murah atau bahkan mahal. Para pihak dapat menunjuk secara tertulis arbiter tunggal atau beberapa arbiter di antara daftar arbiter yang ditetapkan oleh Menteri Tenaga Kerja dan Transmigrasi.

Mekanisme arbitrase harus diselesaikan dalam jangka waktu 30 (tigapuluh) hari, atau, apabila para pihak menyepakati, arbiter dapat memperpanjang jangka waktu penyelesaian 1 (satu) kali perpanjangan selambat-lambatnya 14 (empatbelas) hari kerja. Hal ini akan memungkinkan prosedur arbitrase menjadi cepat, bahkan lebih cepat dibandingkan prosedur penyelesaian melalui Pengadilan Hubungan Industrial yang membutuhkan 50 (limapuluh) hari untuk menyelesaikan 1 (satu) perselisihan.

Ada 4 (empat) macam perselisihan yang diatur dalam UU PPHI, yaitu perselisihan hak, perselisihan kepentingan, perselisihan Pemutusan Hubungan Kerja (PHK), dan perselisihan antar Serikat Pekerja/Serikat Buruh (SP/SB) dalam satu perusahaan. Hanya ada dua perselisihan yang dapat diselesaikan melalui mekanisme arbitrase, yaitu perselisihan kepentingan dan perselisihan antara SP/SB dalam satu perusahaan, dan tidak ada penjelasan mengapa arbitrase dibatasi kewenangannya dalam UU PPHI tersebut.

Arbitrase dalam UU PPHI juga tidak diatur secara rinci, karena salah satu ketentuannya yaitu prosedur penyelesaian melalui arbitrase diserahkan sepenuhnya pada kesepakatan para pihak yang berselisih. Jadi, hal ini akan menimbulkan berbagai macam atau variasi prosedur yang didasarkan pada beberapa hal, yaitu peraturan perundang-undangan yang berlaku, perjanjian, kebiasaan, keadilan, dan kepentingan umum.

Putusan arbitrase didaftarkan di PHI pada PN di wilayah arbiter menetapkan putusan. Salah satu pihak dapat mengajukan permohonan pembatalan putusan arbitrase kepada Mahkamah Agung dalam waktu selambat-lambatnya 30 (tigapuluh) hari kerja sejak ditetapkannya putusan arbitrase, apabila putusan tersebut diduga mengandung unsur-unsur sebagai berikut:

a. Surat atau dokumen yang diajukan dalam pemeriksaan, setelah putusan dijatuhkan, diakui atau dinyatakan palsu;

b. Setelah putusan diambil ditemukan dokumen yang bersifat menentukan, yang disembunyikan oleh pihak lawan; 
c. Putusan diambil dari tipu muslihat yang dilakukan oleh salah satu pihak dalam pemeriksaan perselisihan;

d. Putusan melampuai kekuasaan arbiter hubungan industrial;

e. Putusan bertentangan dengan peraturan perundang-undangan.

Prosedur dalam arbitrase dapat dilihat dalam skema di bawah ini:

Keterangan Skema II:

Skema II.

Prosedur Arbitrase

(Berdasarkan UU PPHI) $^{18}$
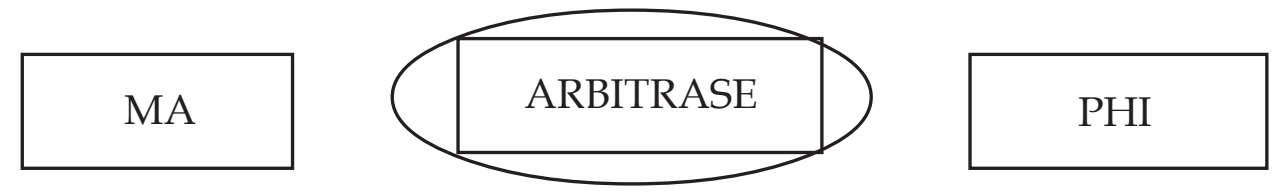

BIPARTIT

1) Apabila para pihak tidak dapat menyelesaiakan perselisihan kepentingan atau perselisihan antar SP/SB hanya dalam satu perusahaan melalui mekanisme bipartit, para pihak dapat mengajukan perselisihannya ke mekanisme arbitrase dan membuat surat perjanjian arbitrase..

2) Putusan arbitrase dapat dimintakan fiat eksekusinya ke PHI pada PN setempat.

3) Salah satu pihak dapat mengajukan pembatalan putusan arbitrase apabila putusan tersebut diduga mengandung beberapa unsur sebagaimana dalam Pasal 52 ayat (1) UU PPHI.

Arbitrase yang diatur di dalam UU PPP dan UU PPHI, dalam perbandingannya, memiliki beberapa persamaan dan perbedaan.

Persamaan arbitrase di dalam ke dua UU tersebut adalah

1. Mekanisme arbitrase dipilih oleh para pihak secara sukarela apabila tidak dapat menyelesaikan perselisihan mereka melalui mekanisme bipartit dan dibuat suatu surat perjanjian arbitrase di antara keduanya, sehingga arbitrase merupakan prosedur yang didasari oleh rasa kepercayaan dan perdamaian dari kedua belah pihak.

2. Mekanisme arbitrase adalah prosedur satu-langkah dan dilakukan di luar pengadilan, sehingga putusan arbitrase akan mengandung penyelesaian yang

${ }^{18}$ Analisis ini didasarkan atas Pasal 44-53 UU PPHI. 
bersifat win-win solution atau menguntungkan kedua belah pihak dan merupakan prosedur secara damai.

3. Putusan arbitrase memiliki sifat terakhir dan mengikat yang berarti putusan tersebut tidak dapat diajukan untuk banding atau kasasi baik ke PHI maupun ke MA, sehingga harus diterima oleh para pihak kecuali ada pembatalan dari MA. Dengan demikian mekanisme arbitrase adalah suatu mekanisme yang sederhana.

4. Arbiter atau para arbiter dipilih atas kesepakatan para pihak sendiri dan secara sukarela, sehingga penunjukkan arbiter didasarkan oleh kepercayaan para pihak dan diyakini bahwa arbiter akan bertindak secara adil dan tidak memihak.

5. Putusan arbiter ditetapkan berdasarkan peraturan perundang-undangan yang berlaku, perjanjian, kebiasaan, keadilan, dan kepentingan umum sehingga akan ada variasi prosedur dalam melaksanakan arbitrase yang sesuai dengan keinginan para pihak karena tidak ada peraturan yang rinci yang harus diikuti oleh para pihak.

6. Biaya dalam proses arbitrase dan honor bagi arbiter dibayar oleh para pihak yang berselisih, sehingga tidak ada standar yang jelas atau pasti dalam penyelesaian melalui mekanisme arbitrase. Dengan demikian kemungkinan akan terjadi pembiayaan yang murah atau bahkan mahal dalam mekanisme arbitrase.

Perbedaan ketentuan arbitrase dalam UU PPHI dan UU PPP adalah

\begin{tabular}{|c|c|c|c|c|}
\hline NO. & KETENTUAN & UU PPP & UU PPHI & KETERANGAN \\
\hline 1. & $\begin{array}{l}\text { Pembatasan } \\
\text { waktu dalam } \\
\text { p r r o s e e s } \\
\text { penyelesaian } \\
\text { perselisihan. }\end{array}$ & Tidak ada & $\begin{array}{l}W \text { a } \mathrm{k} \text { t u } \\
\text { pen y e le sa ia } \mathrm{n} \\
\text { dibatasi hanya } 30 \\
\text { (tiga puluh) hari } \\
\text { yang dapat } \\
\text { diperpanjang satu } \\
\text { kali dalam jangka } \\
\text { 14 (empat belas) } \\
\text { hari kerja. }\end{array}$ & $\begin{array}{lr}\text { Pembatasan } & \text { waktu } \\
\text { dalam UU PPHI dibuat } \\
\text { agar } & \text { proses } \\
\text { penyelesaian } & \text { melalui } \\
\text { arbitraserr dapat } & \text { dilakukan secara cepat } \\
\text { oleh para pihak }\end{array}$ \\
\hline 2. & $\begin{array}{l}\text { C a m p u r } \\
\text { tangan dari } \\
\text { lembaga lain. }\end{array}$ & $\begin{array}{l}\text { Putusan arbiter dapat } \\
\text { dimintakan pengesahan } \\
\text { ke P4Pusat agar dapat } \\
\text { dimintakan fiat eksekusi } \\
\text { ke PN setempat atau } \\
\text { b e r k o n s k u e n s i } \\
\text { hukuman penjara dan/ } \\
\text { atau denda bagi pihak } \\
\text { yang tidak bersedia } \\
\text { melaksanakan putusan } \\
\text { juru/dewan pemisah. }\end{array}$ & $\begin{array}{l}\text { Tidak ada campur } \\
\text { tangan dari } \\
\text { lembaga lain atas } \\
\text { putusan arbitrase } \\
\text { atau tidak ada } \\
\text { k e h a r u a n } \\
\text { p e g e s a h a n } \\
\text { putusan arbitrase } \\
\text { dari lembaga lain. } \\
\text { Putusan arbitrase } \\
\text { cukup untuk }\end{array}$ & $\begin{array}{l}\text { Pengesahan dari } \\
\text { P4Pusat atas putusan } \\
\text { juru/dewan pemisah } \\
\text { menunjukkan bahwa } \\
\text { putusan arbitrase (UU } \\
\text { PPP) dapat dikontrol } \\
\text { oleh P4Pusat, sehingga } \\
\text { pernyataan bahwa } \\
\text { "putusan juru/dewan } \\
\text { pemisah adalah } \\
\text { terakhir dan tetap" }\end{array}$ \\
\hline
\end{tabular}




\begin{tabular}{|c|c|c|c|c|}
\hline NO. & KETENTUAN & UU PPP & UU PPHI & KETERANGAN \\
\hline \multirow[b]{2}{*}{3.} & \multirow[b]{2}{*}{$\begin{array}{l}\text { Pembatasan } \\
\text { o b j e k } \\
\text { penyelesaian } \\
\text { perselisihan. }\end{array}$} & $\begin{array}{l}\text { mengesahkan putusan } \\
\text { juru/dewan pemisah itu } \\
\text { sehingga putusan tidak } \\
\text { dapat dilaksanakan. }\end{array}$ & $\begin{array}{l}\text { didaftarkan di PHI } \\
\text { pada PN setempat } \\
\text { untuk dapat } \\
\text { dimintakan fiat } \\
\text { eksekusinya. }\end{array}$ & $\begin{array}{l}\text { pada dasarnya tidak } \\
\text { mempunyai arti. }\end{array}$ \\
\hline & & $\begin{array}{l}\text { Mekanisme arbitrase } \\
\text { dapat digunakan untuk } \\
\text { menyelesaikan segala } \\
\text { jenis perselisihan, yaitu } \\
\text { perselisihan hak, } \\
\text { p e r s l i s i h a n } \\
\text { kepentingan dan } \\
\text { perselisihan PHK, } \\
\text { sebagaimana yang } \\
\text { diatur dalam UU PPP } \\
\text { maupun UU PHK di } \\
\text { Perusahaan Swasta (UU } \\
\text { 12/1964) }\end{array}$ & $\begin{array}{l}\text { Hanya dapat } \\
\text { digunakan untuk } \\
\text { menyelesaikan } \\
\text { per s lis i h a n } \\
\text { kepentingan dan } \\
\text { perselisihan antara } \\
\text { SP/SB hanya } \\
\text { dalam satu } \\
\text { p e r u s a a a n, } \\
\text { sedangkan untuk } \\
\text { pen y le s a ia n } \\
\text { perselisihan hak } \\
\text { dan perselisihan } \\
\text { PHK hanya dapat } \\
\text { dilakukan melalui } \\
\text { mekanisme selain } \\
\text { arbitrase. }\end{array}$ & $\begin{array}{l}\text { UU 12/1964 tentang } \\
\text { PHK di Perusahaan } \\
\text { Swasra adalah UU yang } \\
\text { merujuk pada } \\
\text { m e k a n i s m e } \\
\text { p e n y l e s a i a n } \\
\text { perselisihan UU PPP } \\
\text { untuk menyelesaikan } \\
\text { perselisihan PHK di } \\
\text { perusahaan swasta. } \\
\text { Tidak ada penjelasan } \\
\text { dalam UU PPHI } \\
\text { mengapa arbitrase } \\
\text { hanya dapat dilakukan } \\
\text { untuk menyelesaikan } \\
\text { dua jenis perselisihan, } \\
\text { yaitu perselisihan hak } \\
\text { dan perselisihan antar } \\
\text { SP/SB hanya dalam satu } \\
\text { perusahaan. }\end{array}$ \\
\hline
\end{tabular}

Persamaan dan perbedaan antara arbitrase sebagaimana tersebut di atas dalam UU PPP dan UU PPHI menunjukkan bahwa arbitrase dalam bidang ketenagakerjaan telah dibangun dan diubah untuk memenuhi karakteristik atau sifat dari prosedur arbitrase yang cepat, sederhana dan murah. Pengaturan arbitrase dalam UU PPHI saat ini lebih baik dibandingkan dengan pengaturan arbitrase dalam UU PPP, terutama dengan mengedepankan mekanisme arbitrase sebagai mekanisme yang damai dan memberikan keuntungan bagi kedua belah pihak.

\section{Arbitrase bagi Kelangsungan Hubungan Kerja di Indonesia.}

Hubungan kerja antara pekerja dan pengusaha adalah bagian dari kondisi ketenagakerjaan yang akan memberikan pengaruh yang besar bagi kelangsungan ekonomi negara Indonesia. Hubungan kerja yang tidak selalu berjalan secara harmonis akan berpengaruh terhadap kondisi perekonomian Indonesia. Dengan demikian, kondisi perekonomian Indonesia dan kondisi hubungan kerja mempunyai 
hubungan yang sangat erat dan saling mempengaruhi satu sama lain. Untuk itu dibutuhkan suatu mekanisme yang damai untuk menyelesaikan perselisihan yang timbul dalam hubungan kerja antara pekerja dan pengusaha, sehingga hubungan kerja akan menjadi harmonis kembali dan terjaga kelangsungannya.

Hubungan kerja yang didasari hubungan yang bersifat perdata antara pekerja dan pengusaha harus pula didasari oleh kehendak dan iktikad baik para pihak, sehingga hubungan tersebut dapat berjalan secara damai dan harmonis. Walaupun iktikad baik tersebut merupakan pengertian yang sangat abstrak ${ }^{19}$ dan pelaksanaannya dapat berbeda satu sama lain, akan tetapi setiap pelaksanaan perjanjian kerja sangat bergantung pada keinginan para pihak. Dengan demikian munculnya suatu perselisihan adalah sangat mungkin terjadi.

Beberapa persyaratan untuk mendukung kebutuhan dalam penyelesaian perselisihan dalam bidang ketenagakerjaan di Indonesia, antara lain: ${ }^{20}$

1. Perlindungan hukum terhadap hak-hak dasar para pihak, pekerja dan pengusaha;

2. Kebebasan dan persamaan bagi para pihak sepanjang proses penyelesaian perselisihan dilakukan;

3. Lebih banyak perlindungan hukum bagi pihak yang lemah, yaitu pekerja, untuk mencapai kebebasan dan persamaan hukum;

4. Menjaga keharmonisan dalam hubungan kerja;

5. Memberikan suatu prosedur yang sederhana, cepat, dan murah;

6. Menjamin kepastian hukum dalam pelaksanaan putusan perselisihan;

7. Memberi kesempatan bagi para pihak untuk mencapai perdamaian selam proses penyelesaian perselisihan dilakukan.

UU PPHI telah menyediakan beberapa mekanisme, baik melalui cara litigasi maupun non-litigasi. Ada suatu pengadilan ketenagakerjaan sebagai cara litigasi yang dibentuk oleh Negara sebagai pengadilan khusus yang menjadi bagian dari Peradilan Umum. Proses beracara di PHI tersebut dilaksanakan sebagaimana hukum acara perdata. Secara umum, hukum acara perdata juga berlandaskan prosedur yang berprinsip sederhana, cepat dan murah. Dalam kenyataannya, penerapan prinsipprinsip tersebut tidak dapat memenuhi keinginan dalam bidang bisnis dan perdagangan. Walaupun kelemahan dari pelaksanaan peradilan dapat saja hanya terjadi di Indonesia, akan tetapi karena kelemahan tersebut menyebabkan kinerja pengadilan Indonesia menjadi tidak efisien dan bahkan menjadikan para pihak rugi. ${ }^{21}$

\footnotetext{
${ }^{19}$ J. Satrio, Hukum Perjanjian (Perjanjian Pada Umumnya), Citra Aditya Bakti, Bandung, 1992, hlm. 365.

${ }^{20}$ Mila Karmila Adi, Op.Cit., hlm. 237-239.

${ }^{21}$ M. Yahya Harahap, Beberapa Tinjanan Mengenai Sistem Peradilan dan Penyelesaian Sengketa, Citra Aditya Bakti, Bandung, 1997, hlm. 147-151.
} 
Mekanisme lainnya adalah negosiasi, mediasi, konsiliasi, dan arbitrase yang termasuk sebagai cara non-litigasi. Sebagaimana telah didiskusikan tentang arbitrase dalam makalah ini, ada beberapa kelebihan arbitrase dibandingkan dengan penyelesaian melalui pengadilan, antara lain:22

a. Ada suatu jaminan kerahasiaan dalam perselisihan antara para pihak;

b. Menghindari proses dan adminitrasi yang lamban;

c. Para pihak dapat memilih arbiter sesuai dengan keyakinan bahwa arbiter memiliki pengetahuan yang memadai, ketrampilan, pengalaman, dan latar belakang tentang kasus yang ditangani, jujur, dan tidak memihak;

d. Para pihak dapat memilih hukum yang akan diterapkan untuk menyelesaikan permasalahan tersebut, prosedur, dan tempat untuk melaksanakan arbitrase;

e. Putusan arbiter adalah mengikat bagi para pihak melalui procedure yang sederhana dan dapat secara langsung dilaksanakan.

Arbitrase di Indonesia telah terbentuk sejak tahun 1977 seiring dengan dibentuknya BANI (Badan Arbitrase Nasional Indonesia). Namun demikian, secara umum BANI tidak dapat bekerja dengan baik dan efektif, sebagaimana laporan ELLIPS Project. Ada beberapa alasan mengapa arbitrase di Indonesia tidak dapat berjalan dengan baik: ${ }^{23}$

1. Kurangnya pengetahuan umum, informasi bagi masyarakat tentang arbitrase, dan perhatian tentang konsepsi dan kelebihan dari arbitrase.

2. Kekhawatiran terhadap putusan arbitrase yang tidak dapat dilaksanakan di Indonesia.

3. Keberadaan klausul-klausul arbitrase yang tidak dapat memberikan keyakinan pelaksanaan perjanjian arbitrase dan penerapan putusan arbitrase.

4. Panel BANI sebagai satu-satunya lembaga yang menyediakan arbiter di Indonesia, sehingga kemungkinan besar akan muncul tekanan politik maupun ekonomi.

Beberapa lembaga yang dapat melaksanakan mekanisme arbitrase dan alternatif penyelesaian sengketa di Indonesia, sebagaimana diatur dalam UU 30/1999, adalah ${ }^{24}$ a. BANI (Badan Arbitrase Nasional Indonesia).

b. BAMUI (Badan Arbitrase Muamalat Islam Indonesia).

c. P3BI (Pusat Penyelesaian Perselisihan Bisnis Indonesia).

d. Jaksa Agung Muda Bidang Perdata dan Tata Usaha Negara (JAMDATUN).

\footnotetext{
${ }^{22}$ Penjelasan Umum Undang-undang Nomor 30 Tahun 1999 tentang Arbitrase and Alternatif Penyelesaian Sengketa.

${ }^{23}$ Normin Pakpahan, His Report on Accomplishment, Plans and Objectives of the Law Development Component of the ELLIPS Projects, Oktober, 1996, sebagaimana dikutip oleh Suyud Margono, ADR (Alternative Dispute Resolution) \& Arbitrase: Proses Pelembagaan dan Aspek Hukum, Citra Aditya Bakti, Bandung, 1997, hlm. 147-151.

${ }^{24}$ Tenne Rustini Wiriaatmadja, Sosialisasi Budaya Hukum Mekanisme Alternatif Penyelesaian Sengketa (MAPS) dalam Upaya Melindungi Para Pelaku Bisnis untuk. Mengantisipasi Era Globalisasi dan Perdagangan Bebas, Laporan Penelitian, UNPAD, Bandung, 1999, hlm. 52-54.
} 
Arbitrase ketenagakerjaan yang disediakan oleh UU PPHI untuk menyelesaikan beberapa perselisihan yang timbul antara pekerja dan pengusaha harus didasarkan pada mekanisme penyelesaian perselisihan bidang ketenagakerjaan. Arbitrase sebagai bagian dari alternatif penyelesaian sengketa secara umum memiliki beberapa kelebihan di bawah ini: ${ }^{25}$

1. Karakteristik atau sifat kesukarelaan dalam prosedur bahwa para pihak memilih arbitrase karena mereka percaya arbitrase memberikan suatu jalan yang potensial untuk menyelesaikan perkara mereka lebih baik daripada proses litigasi. Secara umum, para pihak tidak dapat dipaksa untuk menggunakan prosedur arbitrase, sehingga mereka memilih arbitrase dengan keinginan mereka sendiri.

2. Prosedur yang cepat, karena prosedur arbitrase yang informal, para pihak dapat merundingkan kondisi dari arbitrase. Dengan demikian, para pihak dapat menggunakan setiap prosedur yang disepakati tanpa adanya paksaan untuk menerapkan Hukum Acara Perdata. Hal ini dapat mencegah para pihak dari proses penundaan dan dapat mempercepat prosesnya.

3. Mekanisme yang sederhana, karena arbiter adalah satu-satunya pihak yang memiliki kewenangan memimpin para pihak dalam penyelesaian perselisihan tersebut dan membuat suatu putusan yang terakhir dan tetap, sehingga tidak ada lembaga lain yang dapat mempengaruhi proses arbitrase, bahkan terhadap putusan arbitrase sekalipun.

4. Putusan non-judisial, karena arbiter adalah suatu lembaga privat yang memiliki kewenangan sebagai seorang hakim dalam suatu peradilan umum, sehingga prosedur dan putusan yang dibuat oleh arbiter dipatuhi oleh para pihak sebagai hakim mereka.

5. Penyelesaian secara 'win-win solution' dan mekanisme yang damai bagi para pihak, karena mereka memiliki kesempatan untuk memperoleh putusan yang terbaik bagi mereka dalam suatu prosedur yang informal akan tetapi tetap merupakan cara yang sah.

Arbitrase di Indonesia sejak diatur dalam UU PPP, pada kenyataannya, belum pernah digunakan atau dilaksanakan. Pemilihan arbitrase sebagai mekanisme penyelesaian perselisihan ketenagakerjaan adalah, secara mendasar, merupakan satu bentuk ketakutan untuk menyelesaikan perkara di pengadilan. Saat ini, di Indonesia, waktu rata-rata untuk penyelesaian perselisihan melalui pengadilan kurang lebih 8 - 9 tahun dan tentu saja hal ini menimbulkan suatu pengaruh besar terhadap biaya proses penyelesaian. Beberapa alasan lain yang membuat arbitrase belum pernah digunakan antara lain: ${ }^{26}$

1. Kurangnya peraturan (pelaksanaan);

2. Kurangnya sosialisasi tentang keberadaan arbitrase;

3. Kurangnya kepercayaan para pihak untuk menggunakan arbitrase;

\footnotetext{
${ }^{25}$ UU PPHI.

${ }^{26}$ Wawancara dengan Hanum Hanifah, Maya Lasmita, dan Mochammad Alimuddin, dalam Mila Karmila Adi, Op.Cit., hlm. 172.
} 
4. Ketidakpastian biaya dan waktu;

5. Ketidaksejajaran posisi antara pekerja dan pengusaha dalam hubungan kerja, yaitu pekerja membutuhkan lebih banyak perlindungan hukum dibandingkan pengusaha.

Keberadaan arbitrase sangat penting bagi para pihak untuk melindungi dan membentuk hubungan kerja mereka tetap berlangsung karena kelebihan-kelebihan yang dimiliki arbitrase. Namun demikian, ada beberapa persyarakat yang harus disediakan sehingga arbitrase dapat bermanfaat bagi para pihak, yaitu ${ }^{27}$

1. Kebebasan para pihak untuk memilih prosedur mereka sendiri harus dibuka sehingga perlindungan hukum terhadap hak-hak dasar mereka bisa dipenuhi.

2. Keberadaan arbitrase harus diatur secara jelas dan rinci dalam peraturan perundang-undangan Indonesia untuk memberikan suatu kepastian dan kemudahan prosedur, khususnya dalam penerapan putusan arbitrase.

3. Arbitrase harus disosialisasikan kepada para pihak sebagai salah satu prosedur penyelesaian perselisihan yang sesuai bagi mereka.

4. Harus ada suatu bantuan dana bagi pihak yang lemah, yaitu pekerja, atau bahkan pembatasan biaya dalam melaksanakan proses arbitrase, karena tidak ada standar biaya yang akan membimbing para pihak kepada mekanisme yang murah dalam arbitrase.

5. Harus ada sejumlah arbiter yang memiliki kualifikasi yang baik dan posisi yang netral dalam penyelesaian perselisihan hubungan kerja, sehingga para pihak akan memperoleh penyelesaian yang saling menguntungkan dan adil.

\section{Penutup}

Arbitrase adalah salah satu mekanisme damai untuk menyelesaikan perselisihan hubungan industrial yang sesuai untuk mendukung kelangsungan hubungan kerja di Indonesia. Walaupun arbitrase telah diatur dalam Hukum Ketenagakerjaan Indonesia melalui UU PPP pada 1957, akan tetapi para pihak tidak pernah menggunakan arbitrase untuk menyelesaikan perselisihan mereka. Hal ini dikarenakan beberapa kelemahan dalam arbitrase, antara lain kurangnya pengaturan (peraturan pelaksanaan), kurangnya sosialisasi atas keberadaan arbitrase, dan kurangnya kepercayaan para pihak untuk menggunakan arbitrase.

Masa depan atau prospek arbitrase bagi kelangsungan hubungan kerja di Indonesia adalah kemungkinan kecil akan digunakan oleh para pihak, walaupun pengaturan arbitrase telah diperbaharui dalam UU PPHI pada 2004. Dengan demikian sangat penting untuk melakukan beberapa upaya untuk mendukung arbitrase sebagai salah satu mekanisme penyelesaian perselisihan hubungan industrial, antara lain

${ }^{27}$ Ibid., hlm. 246-247. 
diperlukan lebih banyak pengaturan khususnya peraturan pelaksanaan arbitrase, diperlukan sosialisasi keberadaan arbitrase khususnya bagi para pihak yang terkait dalam hubungan kerja, diperlukan infrastruktur pendukung, dan dukungan dana dalam penerapan arbitrase khususnya bagi pihak pekerja yang secara ekonomi lemah.

\section{Daftar Pustaka}

Adolf, Huala, Arbitrase Komersial Internasional, Cetakan Kedua, Rajawali, Jakarta, 1993.

Basah, Sjahran, Eksistensi dan Tolok Ukur Badan Peradilan Administrasi di Indonesia, Cetakan Ketiga, Alumni, Bandung, 1997.

Husni, Lalu, Penyelesaian Perselisihan Hubungan Industrial melalui Pengadilan $\mathcal{E}$ di luar Pengadilan, PT. Raja Grafindo Persada, Jakarta, 2004.

Karmila Adi, Mila, Penyelesaian Sengketa Ketenagakerjaan secara Arbitrase di Indonesia dalam Era Globalisasi, Tesis, Program Pascasarjana Universitas Padjadjaran, Bandung, 2002.

Margono, Suyud, ADR (Alternative Dispute Resolution) E Arbitrase: Proses Pelembagaan dan Aspek Hukum, Citra Aditya Bakti, Bandung, 1997.

Rustini Wiriaatmadja, Tenne, Sosialisasi Budaya Hukum Mekanisme Alternatif Penyelesaian Sengketa (MAPS) dalam Upaya Melindungi Para Pelaku Bisnis untuk Mengantisipasi Era Globalisasi dan Perdagangan Bebas, Laporan Penelitian, UNPAD, Bandung, 1999.

R. Nolan, Dennis, Labor Arbitrase Law and Practice, Minnesota, West Publishing Company, 1979.

Satrio, J., Hukum Perjanjian (Perjanjian Pada Umumnya), Citra Aditya Bakti, Bandung, 1992.

Soemitro, Rochmat, Masalah Peradilan Administrasi dalam Hukum Pajak di Indonesia, Eresco, Bandung, 1976.

Soepomo, Iman, Hukum Perburuhan Bidang Hubungan Kerja, cetakan kedelapan, Djambatan, Jakarta, 1994.

Usman, Rachmadi, Pilihan Penyelesaian Sengketa di luar Pengadilan, PT. Citra Aditya Bakti, Bandung, 2003.

Yahya Harahap, M., Beberapa Tinjauan Mengenai Sistem Peradilan dan Penyelesaian Sengketa, Citra Aditya Bakti, Bandung, 1997.

Undang-Undang Nomor 22 Tahun 1957 tentang Penyelesaian Perselisihan Perburuhan.

Undang-Undang Nomor 12 Tahun 1964 tentang Pemutusan Hubungan Kerja di Perusahaan Swasta.

Undang-Undang Nomor 30 Tahun 1999 tentang Arbitrase dan Alternatif Penyelesaian Sengketa. 
Undang-Undang Nomor 13 Tahun 2003 tentang Ketenagakerjaan.

Undang-Undang Nomor 2 Tahun 2004 tentang Penyelesaian Perselisihan Hubungan Industrial. 
